\title{
Identification of Race-Specific Resistance in North American Vitis spp. Limiting Erysiphe necator Hyphal Growth
}

\author{
David W. Ramming, Franka Gabler, Joseph L. Smilanick, Dennis A. Margosan, Molly Cadle-Davidson, Paola Barba, \\ Siraprapa Mahanil, Omer Frenkel, Michael G. Milgroom, and Lance Cadle-Davidson
}

First, second, third, and fourth authors: United States Department of Agriculture-Agricultural Research Service (USDA-ARS), San Joaquin Valley Agricultural Sciences Center, Parlier, CA 93648-9757; fifth, seventh, and tenth authors: USDA-ARS Grape Genetics Research Unit, Geneva, NY 14456; sixth author: Department of Horticultural Sciences, Cornell University, Geneva, NY 14456; and eighth and ninth authors: Department of Plant Pathology and Plant-Microbe Biology, Cornell University, Ithaca, NY 14853.

Current address of F. Gabler: California Table Grape Commission, 392 W. Fallbrook, Suite 101, Fresno, CA 93711.

Current address of O. Frenkel: Department of Plant Pathology and Weed Research, ARO, The Volcani Center, P.O. Box 6, Bet Dagan 50250 Israel.

Accepted for publication 17 August 2011.

\begin{abstract}
Ramming, D. W., Gabler, F., Smilanick, J. L., Margosan, D. A., CadleDavidson, M., Barba, P., Mahanil, S., Frenkel, O., Milgroom, M. G., and Cadle-Davidson, L. 2012. Identification of race-specific resistance in North American Vitis spp. limiting Erysiphe necator hyphal growth. Phytopathology 102:83-93.

Race-specific resistance against powdery mildews is well documented in small grains but, in other crops such as grapevine, controlled analysis of host-pathogen interactions on resistant plants is uncommon. In the current study, we attempted to confirm powdery mildew resistance phenotypes through vineyard, greenhouse, and in vitro inoculations for test cross-mapping populations for two resistance sources: (i) a complex hybrid breeding line, 'Bloodworth 81-107-11', of at least Vitis rotundifolia, V. vinifera, V. berlandieri, V. rupestris, V. labrusca, and V. aestivalis background; and (ii) Vitis hybrid 'Tamiami' of V. aestivalis and V. vinifera origin. Statistical analysis of vineyard resistance data suggested the segregation of two and three race-specific resistance genes from the two sources, respectively. However, in each population, some resistant

progeny were susceptible in greenhouse or in vitro screens, which suggested the presence of Erysiphe necator isolates virulent on progeny segregating for one or more resistance genes. Controlled inoculation of resistant and susceptible progeny with a diverse set of E. necator isolates clearly demonstrated the presence of fungal races differentially interacting with race-specific resistance genes, providing proof of race specificity in the grape powdery mildew pathosystem. Consistent with known race-specific resistance mechanisms, both resistance sources were characterized by programmed cell death of host epidermal cells under appressoria, which arrested or slowed hyphal growth; this response was also accompanied by collapse of conidia, germ tubes, appressoria, and secondary hyphae. The observation of prevalent isolates virulent on progeny with multiple race-specific resistance genes before resistance gene deployment has implications for grape breeding strategies. We suggest that grape breeders should characterize the mechanisms of resistance and pyramid multiple resistance genes with different mechanisms for improved durability.
\end{abstract}

Effector triggered immunity (ETI), sometimes called resistance $(R)$-gene-mediated or gene-for-gene resistance, is a common form of disease resistance that is dominantly inherited and straightforward to select in a breeding program (27). However, this type of resistance is typically short lived in the field due to the evolution of races that can overcome a specific resistance. The ETI resistance mechanism is characterized by plants recognizing pathogen effector molecules, either directly or indirectly, via receptors or nucleotide-binding leucine-rich repeat (NB-LRR) $R$ genes and responding by triggering programmed cell death (i.e., a hypersensitive response). If a pathogen can evolve effectors that

Corresponding author: L. Cadle-Davidson;

E-mail address: Lance.CadleDavidson@ars.usda.gov

* The $\boldsymbol{e}$-Xtra logo stands for "electronic extra" and indicates that the online version contains one supplemental figure. Figures 1 and 4 appear in color online.

Mention of trade names or commercial products is solely for the purpose of providing specific information and does not imply recommendation or endorsement by the United States Department of Agriculture.

http://dx.doi.org/10.1094/PHYTO-03-11-0062

This article is in the public domain and not copyrightable. It may be freely reprinted with customary crediting of the source. The American Phytopathological Society, 2012. evade this recognition, a new pathogen race emerges, and the resistance is overcome.

The plant pathogens causing powdery mildews are a collection of obligately biotrophic fungi in the order Erysiphales causing host-specific disease on $\approx 10,000$ plant species, including many agriculturally and horticulturally important crops (23). In many powdery mildew pathosystems, pathogen races have evolved that are virulent on resistant host genotypes $(2,8,15,28-30,32,35)$, several of which have been shown to fit the classic gene-for-gene resistance model proposed by Flor decades ago (17). No races are known in the grape powdery mildew pathosystem, caused by Erysiphe necator (syn. Uncinula necator) on Vitis spp. and other members of the Vitaceae (20). The prominent reliance on fungicide application rather than host resistance to manage grape powdery mildew in commercial production may have obscured any observation of race-specific resistance (20). However, as a result of repeated failures of targeted fungicide classes (14), there is a growing interest in grape cultivars with powdery mildew resistance to complement existing management tactics (20).

In grapevine, the best characterized resistances, Runl and Ren1, have hallmarks of ETI genes, based on their dominant gene action that maps to NB-LRR-encoding regions of the genome, with the resistance phenotype being associated with accelerated single-cell necrosis $(3,9)$. Although not yet deployed in com- 
mercial cultivars, Runl has been introgressed into Vitis vinifera from $V$. rotundifolia, whereas Renl is a rare example of powdery mildew resistance naturally occurring in $V$. vinifera in a few cultivars planted in Central Asia (25).

Eastern North America is likely the center of origin for $E$. necator $(4,19)$. Whereas variation for resistance to powdery mildew exists within all gene pools of the Vitaceae (6), the North American Vitis spp. have been of particular interest. In addition to Runl from $V$. rotundifolia, mapping and quantitative trait loci studies arising from breeding populations derived from North American germplasm have identified Ren2 from $V$. cinerea (10) and Ren3 from the Vitis interspecific hybrid 'Regent' $(1,16,26$, 40). The prevalence and variation for resistance to powdery mildew is indicative of the coevolution of this host and pathogen in North America. In addition to inter- and intraspecific variation in susceptibility, the inconsistency of ratings between environments has been noted (6). For example, V. labrusca accessions planted near Lake Erie, where they were surrounded by juicegrape production (primarily $V$. labrusca interspecific hybrid cultivars), were more susceptible than those planted only $200 \mathrm{~km}$ away in the Finger Lakes region of New York, where they were surrounded by wine-grape production (predominantly $V$. vinifera) (6). One explanation for differential responses to these nearby, similar environments could be the presence of E. necator races in the two different areas, a situation that can be unintentionally selected by long-term monoculture farming systems and one that has been well documented in other powdery mildew pathosystems (15). Although no studies have directly demonstrated differential virulence of $E$. necator isolates on single resistance genes, host specialization has been suggested $(18,21)$, in which isolates were shown to have different host ranges. However, because only a single host genotype was used to represent each Vitis sp., the differential susceptibility described could have been either at the host species level (host specialization) or single-resistance gene level (race specificity) (20).

A consistent, broad-spectrum resistance phenotype conferred by Ren 4 was recently described (34) and mapped to $V$. vinifera chromosome 18 (33). In the current study, we evaluated progeny segregating for powdery mildew resistance from two additional sources: 'Bloodworth 81-107-11' and 'Tamiami', each backcrossed to susceptible $V$. vinifera. Individual progeny of the backcross populations had inconsistent resistance phenotypes, which is in contrast to results in side-by-side tests with progeny segregating for Ren4, for which resistance was consistent (34). This led us to test directly the hypothesis that these two breeding populations were segregating for ETI that could be specific to races of the pathogen present in different locations. We addressed this hypothesis with two objectives: (i) to identify isolates of the pathogen differentially recognized by each of the two resistance sources and (ii) to provide quantitative and descriptive analysis of early pathogenesis on each resistance source, as a reference for future studies.

\section{MATERIALS AND METHODS}

Germplasm. The complex hybrid Bloodworth 81-107-11 was obtained from Jeff Bloodworth, Hillsborough, NC. Its parentage includes at least $V$. rotundifolia, $V$. vinifera, $V$. berlandieri, $V$. rupestris, V. labrusca, and V. aestivalis (Supplemental Figure 1). Vitis hybrid Tamiami is an $\mathrm{F}_{1}$ hybrid resulting from the cross 'Fennell 6' ( $V$. aestivalis $) \times$ 'Malaga' ( $V$. vinifera $)$. These accessions were selected for the breeding program based on their resistance to natural infection by E. necator when grown in Parlier, $\mathrm{CA}$. The segregating $\mathrm{F}_{1}$ populations $02-3517$ and 03-3513 were developed in 2002 and 2003 by the cross Bloodworth 81-107-11 $\times$ 'C67-120' ( $V$. vinifera), which resulted in 9 and 15 segregating progeny, respectively, used in the current study. In 2002, the segregating modified-backcross ${ }_{1}\left(\mathrm{mBC}_{1}\right)$ 02-3512 population with
Tamiami resistance was developed by the crossing B37-28 (Tamiami $\times V$. vinifera) $\times$ C56-11 ( $V$. vinifera), resulting in 94 segregating progeny in the current study. C67-120 (susceptible), B37-28 (resistant), and C56-11 (susceptible) are breeding parents in the United States Department of Agriculture-Agricultural Research Service (USDA-ARS) grape breeding program at Parlier, CA.

Segregating progeny were established in the greenhouse to characterize powdery mildew resistance. For each segregant, 14 dormant cuttings were prepared with the goal of obtaining seven healthy plants: three plants for greenhouse evaluation, two for microscopy, and two for field planting. Cuttings were rooted by dipping in Hormex number 8 rooting powder (Brooker Corp., Chatsworth, CA) and sticking them in sand over bottom heat of $26^{\circ} \mathrm{C}$. When roots were 2 to $5 \mathrm{~cm}$ long, plants were potted, staked, and trained. The above crosses were repeated in 2007, resulting in Bloodworth 81-107-11-derived population 07-3510 and Tamiamiderived population 07-3509 for testing the hypothesis of racespecific resistance and characterizing the resistance mechanism by light microscopy in Geneva, NY.

Greenhouse disease evaluation. Progeny of 02-3517, 033513, and 02-3512 were screened for resistance to powdery mildew as young vines in USDA-ARS, Parlier, CA greenhouses because disease incidence on rooted cuttings can predict the future incidence and severity of mildew infections on mature vines in the vineyard (31). Dormant grapevine cuttings taken in January were rooted and established in the greenhouse in February 2006. Vines in the greenhouse that were several months to 1 year old were grown in Anderson pots, $6.35 \mathrm{~cm}$ square by $17.8 \mathrm{~cm}$ high (Anderson Die and Manufacturing, Portland, OR). Two powdery-mildew-susceptible $V$. vinifera 'Ruby Seedless' vines were placed in the middle of each tray containing 13 randomly placed test vines to provide the natural inoculum source for the test vines. The growing conditions in the greenhouse were $29^{\circ} \mathrm{C}$ during the day and $24^{\circ} \mathrm{C}$ at night with a 12 -h photoperiod maintained by supplemental lighting from 6:00 a.m. to 6:00 p.m. Plants were irrigated as needed and fertilized every 2 weeks. Symptoms were evaluated when $70 \%$ of susceptible control Ruby Seedless leaves exhibited conidiating colonies. After the first evaluation in September 2006, the epidemic was allowed to progress further for a second evaluation in November 2006. The presence of mycelia was confirmed by microscopy. Incidence (percent leaves with one or more powdery mildew colonies) and severity (percent foliage covered by powdery mildew colonies) scores were recorded separately, then averaged and categorized as resistant (R), 0 to 19\%; moderate (M), 20 to 39\%; and susceptible (S), 40 to $100 \%$. The higher index rating from the two dates is presented here.

A similar approach was used to screen for resistance on young vines in USDA-ARS, Geneva, NY greenhouses, in order to identify resistant seedlings for testing the hypothesis of race specificity and for characterizing resistance mechanisms microscopically. Seed of 07-3510 and 07-3509 progeny were germinated in December 2007, resulting in evaluation of 213 and 49 seedlings from the two populations, respectively. Seedlings were maintained in pots, $8.26 \mathrm{~cm}$ square by $8.26 \mathrm{~cm}$ tall (T. O. Plastics, Clearwater, MN). Foliar disease incidence and disease severity ratings were recorded separately when $>70 \%$ of leaves on susceptible 'Chardonnay' seedlings exhibited conidiating colonies. After the first evaluation in August 2008, the epidemic was allowed to progress further for a second evaluation in September 2008. Progeny with no macroscopically visible disease were selected for light microscopy and differential inoculation experiments described here.

Vineyard disease evaluation. Progeny of 02-3517, 03-3513, and 02-3512 were grown at USDA-ARS San Joaquin Valley Agricultural Sciences Center, Parlier, CA. The soil is a fine sandy loam and the vines were drip irrigated. Vines were grown on their own roots at 4-by- $0.5 \mathrm{~m}$ spacing, using a single T-trellis with a 
0.75-m cross-arm on a 2-m stake, and were cane pruned. No fungicides were applied. Highly susceptible $V$. vinifera Ruby Seedless plants were planted every 15 th vine as an inoculum source and to check for the amount of natural powdery mildew infection. Mildew assessments were performed between July and October for 3 years, once the plants started fruiting (in their third growing season). Foliar disease severity ratings were recorded based on percent of foliage covered by powdery mildew colonies: $1=$ no visible infection $(\mathrm{R}), 2$ = very few small colonies $(\mathrm{M}), 3=<50 \%$ coverage $(\mathrm{S})$, and $4=>50 \%$ coverage $(\mathrm{S})$. In all cases, the susceptible Ruby Seedless vines were rated susceptible.

Laboratory disease evaluation. Detached leaves were collected on 12 September 2006, from disease-free potted vines of populations 02-3517, 03-3513, and 02-3512 from the USDAARS, Parlier, CA greenhouse. Up to eight leaves per genotype were collected: the fourth fully expanded leaf and a mature leaf from two replicate shoots per vine and from two replicate vines per genotype. The leaves were stacked in a standardized order, stored in sealed bags at $4{ }^{\circ} \mathrm{C}$, and shipped on ice overnight to Geneva, NY. Upon receipt, leaves were surface sterilized in calcium hypochlorite at $0.88 \mathrm{~g} / \mathrm{liter}$ as described previously (6). The leaves were plated adaxial side up onto 100 -by-15-mm petri dishes containing $18 \mathrm{ml}$ of $1 \%$ water agar amended with natamycin at $0.01 \mathrm{~g} / \mathrm{liter}$ (Haorui Pharma-Chem, Edison, NJ). Residual water was evaporated and inoculation was conducted using isolate 10-18-1 collected from a Chardonnay plant in Dresden, NY in 2003 (6). Spore suspensions were made by shaking leaves with conidiating powdery mildew colonies in $40 \mathrm{ml}$ of distilled water with $0.001 \%$ (vol/vol) Tween 20 (Sigma-Aldrich, St. Louis), and the concentration was adjusted to $5 \times 10^{4}$ conidia/ml using a hemocytometer. Leaves were inoculated using a portable paint sprayer (Preval, Coal City, IL), then placed into a $20 \pm 2^{\circ} \mathrm{C}$ growth chamber with a 12-h photoperiod. Severity was rated visually at 21 days postinoculation as the percentage of leaf area with powdery mildew mycelia in $10 \%$ increments. Resistance responses were categorized as described above.

Resistance characterization. The $V$. vinifera susceptible parent in each test cross population is known to be homozygous recessive for powdery mildew resistance, as crosses among susceptible parents result in all susceptible progeny. Test cross progeny segregate for resistance when the resistant parent is heterozygous for resistance. To determine the number of genes segregating in a given population, phenotypic classes were tested with $\chi^{2}$ goodness-of-fit tests against five predicted ratios, each tested at $\alpha=$ 0.05: 1 resistant $(\mathrm{R})$ to 1 susceptible $(\mathrm{S})$; that is, $1 \mathrm{R}: 1 \mathrm{~S}$, indicating a single dominant resistance gene; $3 \mathrm{R}: 1 \mathrm{~S}$, indicating two dominant genes, either of which alone is sufficient to confer resistance; 7R:1S, indicating three dominant genes, as above, any one of which alone is sufficient to confer resistance; $1 \mathrm{R}: 3 \mathrm{~S}$, indicating two genes, both of which are required for resistance; and 1R:7S, indicating three genes required for resistance. Because some progeny exhibited moderate disease phenotypes, we tested the two extreme scenarios: either all of the moderates are resistant or all are susceptible. This enabled us to empirically determine the maximum effect that improper resistance categorization could have on inferences of segregation ratios.

Low-temperature scanning electron microscopy. A separate set of disease-free, greenhouse-grown plants were maintained for low-temperature scanning electron microscopy (LTSEM). The youngest fully expanded grape leaves were excised from Bloodworth 81-107-11, from Vitis hybrid Tamiami, and from susceptible Vitis progeny 03-3004-16, from a population segregating for Ren4 (34). Each leaf was rinsed in a gentle stream of deionized water and gently blotted dry with a paper towel. Several millimeters of each petiole was removed and the exposed end was inserted into a 17-by-100-mm disposable culture tube filled with deionized water and having a stopper with a hole large enough to allow the petiole to be inserted. Several areas on each leaf were marked with the inked dull end of a cork borer having a $10-\mathrm{mm}$ diameter. The delineated areas on the leaves were inoculated with conidia of E. necator. Conidia were collected by lightly drawing a camel-hair brush over sporulating colonies on leaves of Ruby Seedless grape. The conidia were transferred to the marked areas by gently tapping and rolling the tip of the brush on the grape leaf. The inoculated grape leaves were placed in a plastic box with a false bottom that was suspended over $200 \mathrm{ml}$ of a saturated solution of potassium chloride. The chamber humidity was measured with a PTH-1X temperature humidity meter (Omega Engineering, Inc., Stamford, CT) prior to the introduction of the grape leaves and found to obtain a maximum of $88 \%$ at $24^{\circ} \mathrm{C}$. The lid was placed on the box, the box was placed in a polyethylene bag, and the contents were incubated at $24^{\circ} \mathrm{C}$ for $48 \mathrm{~h}$ before examination by microscopy.

Pieces of the inoculated grape leaves, 5 to $6 \mathrm{~mm}$ on a side, were excised from the inoculated leaf area and mounted on cryo stubs. The mounted leaves were plunge frozen in a liquid nitrogen slurry and transferred to a PP2000 cryo-preparation chamber (Quorum Technologies Ltd., Ringmer, UK). The specimens were heated to sublimate surface ice, coated with gold-palladium, and then transferred to the cryo-stage at a temperature of -178 to $-180^{\circ} \mathrm{C}$ for examination with a Hitachi S3500-N LTSEM (Hitachi High Technologies America, Inc., Pleasanton, CA). Specimens were examined at $5 \mathrm{kV}$ and images digitally recorded. Spore germination, infection structure formation, the presence or absence of host hypersensitive reaction, and colony development were observed on the inoculated grapevine leaves.

Quantification of penetration and microcolony formation. Incompatible resistance phenotypes were quantified at the cell level microscopically, using Coomassie blue staining as previously described (34). The resistant breeding lines 07-3509-109 and 07-3509-162 from Tamiami and 07-3510-14 from Bloodworth 81-107-11 were compared with the susceptible check $V$. vinifera 'Riesling'. The third- and fourth-youngest leaves were detached, surface sterilized as described above, and placed on $1 \%$ agar for all assays. Leaves with actively conidiating colonies of an incompatible isolate were used for inoculation by touching conidiating colonies directly to the inoculated leaf. Plates containing inoculated leaves were incubated at $20^{\circ} \mathrm{C}$ for 3 days. Four discs were collected from each leaf for staining with Coomassie blue (12) and the experiment was conducted twice. Leaf discs $\left(1 \mathrm{~cm}^{2}\right)$ were collected by cork borer and placed in a 24 -well plate for clearing in 3:1 ( $\mathrm{vol} / \mathrm{vol})$ ethanol/acetic acid, changing the solution three to four times until the tissue was completely bleached, and then in 50\% ethanol for long-term storage. The solution was replaced with Coomassie blue stain (Coomassie Brilliant Blue R250 at $0.12 \mathrm{~g} /$ liter in an aqueous solution containing $50 \%$ [vol/vol] methanol and $10 \%$ [vol/vol] glacial acetic acid) for 5 to $10 \mathrm{~s}$ to stain the mycelium, then rinsed with several water changes and mounted for viewing on a microscope slide in 50\% glycerol.

We quantified penetration and microcolony formation by randomly sampling $\geq 50$ germinated conidia per leaf disc with a compound light microscope at $\times 100$ to 200 magnification. Each germinated conidium was categorized as having (i) a primary hypha leading to an appressorium, (ii) a single unbranched secondary hypha at least twice as long as the conidium, or (iii) multiple or branching secondary hyphae. Penetration was quantified as the proportion of spores in categories ii and iii, because secondary hyphae only develop after successful penetration; microcolony formation was quantified as the proportion of spores in category iii. The total numbers of conidia observed for quantifying penetration and microcolony success on each seedling were 954 for 07-3509-109, 235 for 07-3509-162, 964 for 07-3510-14, and 1,014 for Riesling. Confidence limits $(95 \%)$ for the proportion of successful conidia were determined as previously described (34). For each leaf disc, 10 conidia that successfully penetrated were selected and, for each conidium, the total hyphal length was 
measured by ocular micrometer. The numbers of conidia observed for quantification of hyphal length on each seedling were 74 for 07-3509-109, 17 for 07-3509-162, 45 for 07-3510-14, and 58 for Riesling. Average hyphal length was analyzed using analysis of variance with the predictors: genotype, leaf age, disc, and genotype-leaf age.

Fungal isolate screening. E. necator isolates were collected from several Vitis hosts growing wild or cultivated in diverse locations in the eastern half of the United States $(4,19)$, and single-conidium colonies were prepared as described by Brewer and Milgroom (4). Isolates used here included BlMtnt2 (from $V$. aestivalis), LICY (V. vinifera Chardonnay), PUMOChn (Vitis hybrid 'Chambourcin'), WVMONt (Vitis hybrid 'Norton'), PCTH (V. rotundifolia), LNYM (V. vinifera 'Merlot'), G9 (Vitis hybrid 'Rosette'), and SHNC1 (Vitis hybrid Chambourcin), each belonging to a different haplotype based on a multilocus sequencing (4). Several progeny from the populations of Tamiami (07-3509-109, $-162,-178,-191,-215$, and susceptible checks -40 and -96) and
Bloodworth 81-107-11 (07-3510-70 and susceptible check -31) were screened for resistance against each isolate using a detached leaf assay described by Frenkel et al. (18). Resistant Bloodworth 81-107-11 progeny 07-3510-03 and -32 were also screened and supported the results of $07-3510-70$ but were returned to the breeding program in Parlier, CA, before the experiment could be repeated in Geneva, NY. Dry inoculation was conducted by applying $\approx 200$ conidia to the center of the leaf with a sterile pipette tip. Inoculation experiments were repeated a minimum of three times, and isolates were judged compatible when they successfully sporulated, as observed under $\times 10$ to 20 magnification, by 16 days postinoculation.

\section{RESULTS}

Progeny segregation due to heterozygosity of resistant parents. In the breeding vineyard in Parlier, CA, progeny of the Tamiami test cross B37-28 $\times$ C56-11 segregated across four

TABLE 1. Powdery mildew disease ratings on progeny from a Vitis interspecific hybrid 'Tamiami' $\times$ Vitis vinifera modified-backcross under greenhouse, vineyard, or laboratory conditions

\begin{tabular}{|c|c|c|c|c|c|c|}
\hline \multirow[b]{2}{*}{ Progeny } & \multicolumn{2}{|c|}{ California greenhouse $^{a}$} & \multicolumn{2}{|c|}{ California vineyard ${ }^{\mathrm{b}}$} & \multicolumn{2}{|c|}{ New York laboratoryc } \\
\hline & Index & Rating & Severity & Rating & Coverage & Rating \\
\hline C83-235 & 0 & $\mathrm{R}$ & 1 & $\mathrm{R}$ & 0 & $\mathrm{R}$ \\
\hline C84-66 & 0 & $\mathrm{R}$ & 1 & $\mathrm{R}$ & 0 & $\mathrm{R}$ \\
\hline C83-233 & 2 & $\mathrm{R}$ & 1 & $\mathrm{R}$ & 60 & $\mathrm{~S}$ \\
\hline C83-262 & 5 & $\mathrm{R}$ & 1 & $\mathrm{R}$ & 80 & $\mathrm{~S}$ \\
\hline C83-238 & 5 & $\mathrm{R}$ & 1 & $\mathrm{R}$ & nd & $*$ \\
\hline C83-256 & 7 & $\mathrm{R}$ & 1 & $\mathrm{R}$ & 20 & M \\
\hline C83-259 & 8 & $\mathrm{R}$ & 1 & $\mathrm{R}$ & 0 & $\mathrm{R}$ \\
\hline C84-26 & 8 & $\mathrm{R}$ & 1 & $\mathrm{R}$ & 60 & $\mathrm{~S}$ \\
\hline C84-02 & 9 & $\mathrm{R}$ & 1 & $\mathrm{R}$ & 0 & $\mathrm{R}$ \\
\hline C84-55 & 9 & $\mathrm{R}$ & 1 & $\mathrm{R}$ & 40 & $\mathrm{~S}$ \\
\hline C84-15 & 10 & $\mathrm{R}$ & 1 & $\mathrm{R}$ & 0 & $\mathrm{R}$ \\
\hline C83-237 & 11 & $\mathrm{R}$ & 1 & $\mathrm{R}$ & nd & nd \\
\hline C84-04 & 16 & $\mathrm{R}$ & 1 & $\mathrm{R}$ & 0 & $\mathrm{R}$ \\
\hline C84-91 & $21(0)$ & M & 1 & $\mathrm{R}$ & 0 & $\mathrm{R}$ \\
\hline C83-257 & 22 & M & 1 & $\mathrm{R}$ & 70 & $\mathrm{~S}$ \\
\hline C84-05 & 23 & M & 1 & $\mathrm{R}$ & 40 & $\mathrm{~S}$ \\
\hline C84-12 & 24 & M & 1 & $\mathrm{R}$ & nd & $*$ \\
\hline C83-253 & 25 & M & 1 & $\mathrm{R}$ & nd & * \\
\hline $\mathrm{C} 83-250$ & $26(0)$ & M & 1 & $\mathrm{R}$ & 20 & M \\
\hline C84-13 & $26(0)$ & M & 1 & $\mathrm{R}$ & 20 & M \\
\hline C83-236 & $26(0)$ & M & 1 & $\mathrm{R}$ & 30 & M \\
\hline C84-73 & 28 & M & 1 & $\mathrm{R}$ & nd & * \\
\hline C83-263 & $28(0)$ & M & 1 & $\mathrm{R}$ & 90 & $\mathrm{~S}$ \\
\hline $\mathrm{C} 84-37$ & 29 & M & 1 & $\mathrm{R}$ & nd & nd \\
\hline C84-01 & $29(0)$ & M & 1 & $\mathrm{R}$ & 20 & M \\
\hline C84-56 & 30 & M & 1 & $\mathrm{R}$ & 20 & M \\
\hline
\end{tabular}

(continued on next page)

${ }^{a}$ California greenhouse ratings of natural epidemics were recorded in September and November 2006. Incidence and severity scores were averaged here and reported as an index, with the higher index rating from the two dates being presented here. When the index increased by $\geq 20 \%$ from September to November, the September index rating is included in parentheses. Ratings in bold italics denote vines on which powdery mildew colonies were observed on senescing leaves; $\mathrm{nd}=$ not determined. Index ratings were categorized as 0 to $19 \%=$ resistant (R), 20 to $39 \%=$ moderate (M), and 40 to $100 \%=$ susceptible (S).

${ }^{\mathrm{b}}$ California vineyard ratings of natural foliar disease severity were recorded and categorized as $1=$ no infection $(\mathrm{R}), 2=$ very few small colonies $(\mathrm{M}), 3=<50 \%$ coverage (S), and $4=>50 \%$ coverage $(\mathrm{S})$.

${ }^{\mathrm{c}}$ Detached leaves in petri dishes were inoculated in laboratory conditions with a single-spored isolate from New York, 10-18-1. Maximum percent leaf coverage was rated in $10 \%$ increments and categorized as: 0 to $19 \%=\mathrm{R}, 20$ to $39 \%=\mathrm{M}$, and 40 to $100 \%=\mathrm{S}$; nd = not determined. 
categories of foliar disease severity $(1=$ no visible infection, R; $2=$ very few small colonies, $M ; 3=<50 \%$ coverage, $S$; and $4=$ $>50 \%$ severity, $\mathrm{S}$ ) as $84: 3: 4: 3$, respectively (Table 1 ). The cuttings of the test cross population Bloodworth 81-107-11 $\times$ C67-120 rooted poorly, resulting in the small number of progeny (24 individuals). Progeny of this population also segregated across the spectrum of resistance categories as 17:1:1:5 (Table 2). All susceptible checks were rated susceptible, indicating that resistance was not due to escape from infection. By inference, segregation in each test cross suggested that the resistant parent was heterozygous for at least one dominant resistance gene. Goodness-of-fit tests indicated that segregation ratios from Tamiami were consistent with 7:1, suggesting segregation of three dominant resistance genes (Table 3). Bloodworth 81-107-11 progeny segregated 3:1, suggesting two dominant resistance genes (Table 4).

Inconsistency of ratings by resistance screen. In each population, vegetatively propagated cuttings of some individual progeny had different resistance ratings for each resistance screen, resulting in resistance ratios that differed for each screen. Although the 7:1 vineyard ratio for Tamiami progeny had suggested segregation of three independent resistance genes, any of which was sufficient for resistance, ratios of $1: 1$ or $1: 3$ in the singleisolate and greenhouse screens (Table 3) suggested that subsets of resistance genes were not sufficient for resistance in all screens. Similarly, whereas the 3:1 vineyard ratio for Bloodworth 81-10711 progeny had suggested the segregation of at least two independent resistance genes, any of which was sufficient for resistance, ratios of $1: 3$ and 1:1 for the greenhouse and singleisolate screens suggested that subsets of resistance genes were not sufficient for resistance in all screens (Table 4).

This inconsistency by resistance screen is apparent in Tables 1 and 2. For example, individual Tamiami progeny C84-18 was susceptible to natural infection in the Parlier, CA greenhouse $(64 \%)$ but resistant to natural infection in the vineyard (no visible

TABLE 1. (continued from preceding page)

\begin{tabular}{|c|c|c|c|c|c|c|}
\hline \multirow[b]{2}{*}{ Progeny } & \multicolumn{2}{|c|}{ California greenhouse ${ }^{a}$} & \multicolumn{2}{|c|}{ California vineyard ${ }^{\mathrm{b}}$} & \multicolumn{2}{|c|}{ New York laboratory ${ }^{c}$} \\
\hline & Index & Rating & Severity & Rating & Coverage & Rating \\
\hline C83-248 & $34(0)$ & M & 1 & $\mathrm{R}$ & 50 & $\mathrm{~S}$ \\
\hline C83-249 & 35 & M & 1 & $\mathrm{R}$ & 50 & $\mathrm{~S}$ \\
\hline $\mathrm{C} 84-88$ & 35 & M & 1 & $\mathrm{R}$ & nd & $*$ \\
\hline C84-32 & 36 & M & 1 & $\mathrm{R}$ & 0 & $\mathrm{R}$ \\
\hline C84-44 & 36 & M & 1 & $\mathrm{R}$ & 0 & $\mathrm{R}$ \\
\hline C84-63 & 36 & M & 1 & $\mathrm{R}$ & 20 & M \\
\hline C84-87 & 37 & M & 1 & $\mathrm{R}$ & 90 & $\mathrm{~S}$ \\
\hline C84-50 & 38 & M & 1 & $\mathrm{R}$ & nd & $*$ \\
\hline C84-83 & $38(0)$ & M & 1 & $\mathrm{R}$ & 0 & $\mathrm{R}$ \\
\hline C84-54 & 39 & $\mathrm{M}$ & 1 & $\mathrm{R}$ & 0 & $\mathrm{R}$ \\
\hline C84-61 & 40 & $\mathrm{~S}$ & 1 & $\mathrm{R}$ & 0 & $\mathrm{R}$ \\
\hline C84-21 & 40 & $\mathrm{~S}$ & 1 & $\mathrm{R}$ & 40 & $\mathrm{~S}$ \\
\hline C84-51 & 41 & $\mathrm{~S}$ & 1 & $\mathrm{R}$ & 0 & $\mathrm{R}$ \\
\hline C83-244 & 41 (18) & $\mathrm{S}$ & 1 & $\mathrm{R}$ & 50 & $\mathrm{~S}$ \\
\hline C84-11 & $41(5)$ & $\mathrm{S}$ & 1 & $\mathrm{R}$ & nd & $*$ \\
\hline C83-258 & $42(6)$ & $\mathrm{S}$ & 2 & M & 50 & $\mathrm{~S}$ \\
\hline C84-98 & $43(20)$ & $\mathrm{S}$ & 1 & $\mathrm{R}$ & 20 & $\mathrm{M}$ \\
\hline C84-24 & 44 & $\mathrm{~S}$ & 1 & $\mathrm{R}$ & 0 & $\mathrm{R}$ \\
\hline C84-31 & 45 & $\mathrm{~S}$ & 1 & $\mathrm{R}$ & 100 & $\mathrm{~S}$ \\
\hline C84-14 & $45(0)$ & $\mathrm{S}$ & 1 & $\mathrm{R}$ & nd & $*$ \\
\hline C84-53 & 46 & S & 3 & $\mathrm{~S}$ & 0 & $\mathrm{R}$ \\
\hline C84-30 & $46(22)$ & $\mathrm{S}$ & 1 & $\mathrm{R}$ & 0 & $\mathrm{R}$ \\
\hline C84-82 & 47 & $\mathrm{~S}$ & 1 & $\mathrm{R}$ & 50 & $\mathrm{~S}$ \\
\hline C84-19 & $47(21)$ & $\mathrm{S}$ & 2 & M & 40 & $\mathrm{~S}$ \\
\hline C84-29 & 48 (19) & $\mathrm{S}$ & 1 & $\mathrm{R}$ & 90 & $\mathrm{~S}$ \\
\hline C84-84 & 50 & S & 1 & $\mathrm{R}$ & 30 & M \\
\hline C84-59 & $51(31)$ & $\mathrm{S}$ & 1 & $\mathrm{R}$ & nd & $*$ \\
\hline C84-22 & 52 & $S$ & 1 & $\mathrm{R}$ & 0 & $\mathrm{R}$ \\
\hline C84-35 & $52(22)$ & $\mathrm{S}$ & 1 & $\mathrm{R}$ & nd & $*$ \\
\hline C84-47 & $52(29)$ & $\mathrm{S}$ & 1 & $\mathrm{R}$ & 60 & $\mathrm{~S}$ \\
\hline C84-06 & $53(27)$ & $\mathrm{S}$ & 1 & $\mathrm{R}$ & 0 & $\mathrm{R}$ \\
\hline C84-28 & $54(10)$ & $\mathrm{S}$ & 1 & $\mathrm{R}$ & 90 & $\mathrm{~S}$ \\
\hline C84-68 & 55 & $\mathrm{~S}$ & 1 & $\mathrm{R}$ & nd & $*$ \\
\hline C84-07 & 57 & $\mathrm{~S}$ & 1 & $\mathrm{R}$ & nd & nd \\
\hline C84-75 & 58 & $\mathrm{~S}$ & 4 & $\mathrm{~S}$ & 30 & $\mathrm{M}$ \\
\hline C84-36 & 58 & $\mathrm{~S}$ & 1 & $\mathrm{R}$ & nd & $*$ \\
\hline C84-34 & $58(11)$ & $S$ & 1 & $\mathrm{R}$ & nd & $*$ \\
\hline C84-25 & 60 & $\mathrm{~S}$ & 1 & $\mathrm{R}$ & 0 & $\mathrm{R}$ \\
\hline C84-69 & $63(18)$ & $S$ & 1 & $\mathrm{R}$ & nd & $*$ \\
\hline C84-18 & $64(28)$ & $\mathrm{S}$ & 1 & $\mathrm{R}$ & 0 & $\mathrm{R}$ \\
\hline C84-42 & 68 & $\mathrm{~S}$ & 1 & $\mathrm{R}$ & nd & $*$ \\
\hline C84-77 & 68 & $\mathrm{~S}$ & 3 & $\mathrm{~S}$ & nd & $*$ \\
\hline C84-78 & 69 & $\mathrm{~S}$ & 1 & $\mathrm{R}$ & 60 & $\mathrm{~S}$ \\
\hline C84-38 & $70(26)$ & $\mathrm{S}$ & 1 & $\mathrm{R}$ & nd & nd \\
\hline C84-49 & $72(43)$ & $\mathrm{S}$ & 1 & $\mathrm{R}$ & nd & $*$ \\
\hline C84-33 & 77 (26) & $\mathrm{S}$ & 1 & $\mathrm{R}$ & 0 & $\mathrm{R}$ \\
\hline C84-76 & $78(46)$ & $\mathrm{S}$ & 3 & $\mathrm{~S}$ & 70 & $\mathrm{~S}$ \\
\hline C84-70 & $81(38)$ & $\mathrm{S}$ & 1 & $\mathrm{R}$ & nd & $*$ \\
\hline C84-79 & 82 & $\mathrm{~S}$ & 4 & $\mathrm{~S}$ & nd & nd \\
\hline C84-41 & 84 (29) & $\mathrm{S}$ & 1 & $\mathrm{R}$ & 0 & $\mathrm{R}$ \\
\hline C84-95 & 91 & $\mathrm{~S}$ & 4 & $\mathrm{~S}$ & 30 & $\mathrm{M}$ \\
\hline C84-45 & 92 & $\mathrm{~S}$ & 1 & $\mathrm{R}$ & nd & nd \\
\hline C84-09 & $92(55)$ & $\mathrm{S}$ & 2 & M & nd & nd \\
\hline
\end{tabular}


infection) or to inoculation with isolate 10-18-1 (0\%) (Table 1). Bloodworth 81-107-11 progeny C84-252 was susceptible to natural infection in the Parlier, CA greenhouse $(85 \%)$ but resistant to natural infection in the vineyard (no visible infection) and had a moderate response to inoculation with isolate 10-18-1 (20\%) (Table 2). A testable hypothesis was that inconsistency in resistance phenotype among screens was the result of differences in the pathogen genotypes with respect to race specificity, though this inconsistency could be due to other experimental or environmental differences.

Evidence of race specificity by differential infection. Given the inconsistency among screens in the inferred models for the inheritance of resistance, we directly tested the hypothesis that progeny segregated for race-specific resistance. Five singleconidium E. necator isolates were inoculated on segregants from the Tamiami and Bloodworth 81-107-11 modified-backcross populations. These isolates were differential in their ability to form colonies and sporulate (Table 5). We tested five Tamiami progeny previously shown to be resistant to natural infection, and all five supported sporulation by either isolate BlMtnt2 (collected from $V$. aestivalis), isolate WVMONt (from the interspecific $V$. aestivalis hybrid Norton), or both. Two progeny supported sporulation by LICY and PUMOChn (collected from V. vinifera Chardonnay and Vitis hybrid Chambourcin, respectively) in some replicates.

A Bloodworth 81-107-11 progeny that was resistant to natural infection was also resistant to several isolates but supported sporulation by isolate PUMOChn in multiple experiments (Table 5 ) and by isolate PCTH (collected from V. rotundifolia) in one experiment before isolate PCTH was contaminated by mycoparasites. Supporting these results, resistant Bloodworth 81-10711 progeny $07-3510-03$ and -32 were differentially infected by $E$. necator isolates, with BlMtnt2 and LICY compatible and WVMONt incompatible (data not shown). Isolates compatible with Bloodworth 81-107-11 progeny elicited visible host epidermal necrosis underlying each appressorium, but this slow, "trailing" necrosis could not halt colony development (Fig. 1).

TABLE 2. Powdery mildew disease ratings on progeny from a complex hybrid 'Bloodworth 81-107-11' modified-backcross under greenhouse, vineyard, or laboratory conditions

\begin{tabular}{|c|c|c|c|c|c|c|}
\hline \multirow[b]{2}{*}{ Progeny } & \multicolumn{2}{|c|}{ California greenhouse $\mathrm{a}^{\mathrm{a}}$} & \multicolumn{2}{|c|}{ California vineyard ${ }^{\mathrm{b}}$} & \multicolumn{2}{|c|}{ New York laboratory ${ }^{\mathrm{c}}$} \\
\hline & Index & Rating & Severity & Rating & Coverage & Rating \\
\hline C84-229 & 0 & $\mathrm{R}$ & 1 & $\mathrm{R}$ & 0 & $\mathrm{R}$ \\
\hline Y313-60 & 0 & $\mathrm{R}$ & 1 & $\mathrm{R}$ & 0 & $\mathrm{R}$ \\
\hline C84-225 & 6 & $\mathrm{R}$ & 1 & $\mathrm{R}$ & 40 & $\mathrm{~S}$ \\
\hline C84-224 & 14 & $\mathrm{R}$ & 1 & $\mathrm{R}$ & 40 & $\mathrm{~S}$ \\
\hline Y313-63 & 17 & $\mathrm{R}$ & 1 & $\mathrm{R}$ & 20 & M \\
\hline Y313-49 & 56 & $\mathrm{~S}$ & 2 & M & 60 & $\mathrm{~S}$ \\
\hline Y313-54 & 59 & $\mathrm{~S}$ & 1 & $\mathrm{R}$ & 20 & M \\
\hline Y313-46 & 59 & $\mathrm{~S}$ & 1 & $\mathrm{R}$ & 70 & $\mathrm{~S}$ \\
\hline C84-232 & $61(10)$ & $\mathrm{S}$ & 1 & $\mathrm{R}$ & 60 & $\mathrm{~S}$ \\
\hline Y313-55 & 64 & $\mathrm{~S}$ & 1 & $\mathrm{R}$ & 70 & $\mathrm{~S}$ \\
\hline Y313-62 & $64(7)$ & $\mathrm{S}$ & 1 & $\mathrm{R}$ & 30 & $\mathrm{M}$ \\
\hline Y313-66 & 91 & $\mathrm{~S}$ & 4 & $\mathrm{~S}$ & 40 & $\mathrm{~S}$ \\
\hline Y313-67 & 93 & $\mathrm{~S}$ & 4 & $\mathrm{~S}$ & 70 & $\mathrm{~S}$ \\
\hline Y313-51 & 96 & $\mathrm{~S}$ & 4 & $\mathrm{~S}$ & nd & nd \\
\hline C84-234 & nd & nd & 1 & $\mathrm{R}$ & 20 & M \\
\hline
\end{tabular}

${ }^{a}$ California greenhouse ratings of natural epidemics were recorded in September and November 2006. Incidence and severity scores were averaged here and reported as an index, with the higher index rating from the two dates being presented here. When the index increased by $\geq 20 \%$ from September to November, the September index rating is included in parentheses. Ratings in bold italics denote vines on which powdery mildew colonies were observed on senescing leaves; nd $=$ not determined. Index ratings were categorized as 0 to $19 \%=$ resistant $(\mathrm{R}), 20$ to $39 \%=$ moderate $(\mathrm{M})$, and 40 to $100 \%=$ susceptible $(\mathrm{S})$.

${ }^{\mathrm{b}}$ California vineyard ratings of natural foliar disease severity were recorded and categorized as $1=$ no infection $(\mathrm{R}), 2=$ very few small colonies $(\mathrm{M}), 3=<50 \%$ coverage $(\mathrm{S})$, and $4=>50 \%$ coverage $(\mathrm{S})$.

${ }^{c}$ Detached leaves in petri dishes were inoculated in laboratory conditions with a single-spored isolate from New York, 10-18-1. Maximum percent leaf coverage was rated in $10 \%$ increments and categorized as 0 to $19 \%=\mathrm{R}, 20$ to $39 \%=\mathrm{M}$, and 40 to $100 \%=\mathrm{S}$; nd = not determined.

TABLE 3. Segregation ratios and $\chi^{2}$ goodness-of-fit test suggesting race specificity of Vitis hybrid 'Tamiami' resistance in the cross B37-28 $\times$ C56-11

\begin{tabular}{|c|c|c|c|c|c|c|c|c|}
\hline \multirow[b]{2}{*}{ Location } & \multirow[b]{2}{*}{ Threshold $^{\mathrm{a}}$} & \multicolumn{2}{|c|}{$\begin{array}{l}\text { Proportion of progeny } \\
\text { in each class }\end{array}$} & \multicolumn{5}{|c|}{$P$ value for $\chi^{2}$ goodness-of-fit test per model ${ }^{\mathrm{b}}$} \\
\hline & & Resistant & Susceptible & $7: 1$ & $3: 1$ & $1: 1$ & $1: 3$ & $1: 7$ \\
\hline \multirow[t]{2}{*}{ California vineyard } & 2 & 0.89 & 0.11 & 0.5852 & 0.0013 & 0.0001 & 0.0001 & 0.0001 \\
\hline & 3 & 0.93 & 0.07 & 0.1385 & 0.0001 & 0.0001 & 0.0001 & 0.0001 \\
\hline \multirow[t]{2}{*}{ California greenhouse } & $20 \%$ & 0.22 & 0.78 & 0.0001 & 0.0001 & 0.0001 & 0.5515 & 0.0039 \\
\hline & $40 \%$ & 0.54 & 0.46 & 0.0001 & 0.0001 & 0.4093 & 0.0001 & 0.0001 \\
\hline \multirow[t]{2}{*}{ New York laboratory } & $20 \%$ & 0.39 & 0.61 & 0.0001 & 0.0001 & 0.0801 & 0.0008 & 0.0001 \\
\hline & $40 \%$ & 0.61 & 0.39 & 0.0001 & 0.0008 & 0.0801 & 0.0001 & 0.0001 \\
\hline
\end{tabular}

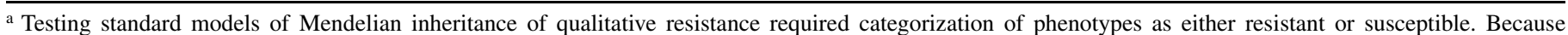
categorization could result in different segregation ratios depending on the threshold selected for susceptibility, we analyzed ratios either including progeny with moderate disease $(2=$ very few small colonies) as susceptible (lower threshold) or including them as resistant (higher threshold).

b Models with $P$ values $<0.05$ are rejected and in italics; the most likely model is highlighted in bold. 
Mechanism of resistance. Race-specific resistances to powdery mildews typically allow penetration and formation of secondary hyphae before restricting hyphal growth. As quantified using light microscopy, resistant progeny from each population had moderately reduced levels of penetration and microcolony formation relative to the susceptible Riesling (Fig. 2). However, hyphal length on susceptible and resistant genotypes showed pronounced and significant $(P<0.0001)$ differences (Figs. 3 and 4). Examination of the inoculated grape leaves by LTSEM showed that, on a susceptible genotype, E. necator conidia germinated (often forming two germ tubes), formed appressoria, and, as the germ tubes continued to grow, formed appressoria at frequent intervals along the hyphae (Fig. 5). In contrast, on leaves of Tamiami and Bloodworth 81-107-11, conidia germinated and formed a single germ tube and primary appressorium. Conidia, germ tubes, and appressoria collapsed on the resistant leaves, consistent with moderate penetration resistance observed using light microscopy. When further hyphal growth occurred, the hypha did not form additional appressoria and also collapsed within $48 \mathrm{~h}$ postinoculation, consistent with short hyphal length observed using light microscopy.

\section{DISCUSSION}

The existence of races of $E$. necator has been hypothesized and supported anecdotally for decades $(6,13,37,39)$. The data pre-

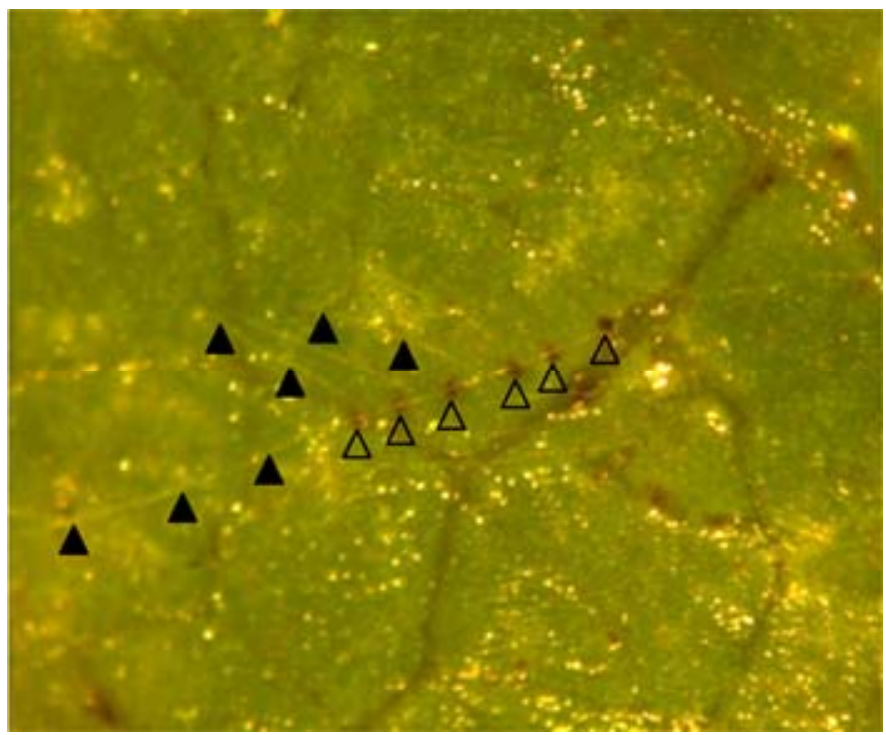

Fig. 1. Microcolony development on a resistant segregant of 'Bloodworth 81107-11' population 07-3510 when inoculated with a virulent isolate. For isolates that overcome resistance from Bloodworth 81-107-11, host necrosis (subtended by open triangles) is still observed but is not rapid enough to prevent colony development and, thus, appears to "trail" the leading edge of hyphal growth (subtended by filled triangles), a phenotype referred to here as "trailing necrosis."

TABLE 4. Segregation ratios and $\chi^{2}$ goodness-of-fit test suggesting race specificity of Vitis hybrid 'Bloodworth 81-107-11' resistance in the cross Bloodworth 81 $107-11 \times$ C $67-120$

\begin{tabular}{|c|c|c|c|c|c|c|c|c|}
\hline \multirow[b]{2}{*}{ Location } & \multirow[b]{2}{*}{ Threshold $^{\mathrm{a}}$} & \multicolumn{2}{|c|}{$\begin{array}{l}\text { Proportion of progeny } \\
\text { in each class }\end{array}$} & \multicolumn{5}{|c|}{$P$ value for $\chi^{2}$ goodness-of-fit test per model ${ }^{\mathrm{b}}$} \\
\hline & & Resistant & Susceptible & $7: 1$ & $3: 1$ & $1: 1$ & $1: 3$ & $1: 7$ \\
\hline \multirow[t]{2}{*}{ California vineyard } & 2 & 0.71 & 0.29 & 0.0136 & 0.6374 & 0.0412 & 0.0001 & 0.0001 \\
\hline & 3 & 0.75 & 0.25 & 0.0641 & 1.0000 & 0.0143 & 0.0001 & 0.0001 \\
\hline \multirow[t]{2}{*}{ California greenhouse } & $20 \%$ & 0.26 & 0.74 & 0.0001 & 0.0001 & 0.0218 & 0.9042 & 0.0488 \\
\hline & $40 \%$ & 0.30 & 0.70 & 0.0001 & 0.0001 & 0.0606 & 0.5472 & 0.0093 \\
\hline \multirow[t]{2}{*}{ New York laboratory } & $20 \%$ & 0.14 & 0.86 & 0.0001 & 0.0001 & 0.0011 & 0.2568 & 0.0610 \\
\hline & $40 \%$ & 0.43 & 0.57 & 0.0001 & 0.0007 & 0.4290 & 0.0588 & 0.0001 \\
\hline
\end{tabular}

a Models with $P$ values $<0.05$ are rejected and in italics; the most likely model is highlighted in bold.

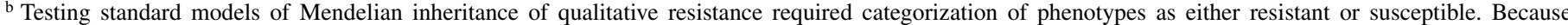
categorization could result in different segregation ratios depending on the threshold selected for susceptibility, we analyzed ratios either including moderate (M) progeny as susceptible (susceptible thresholds $=2$ [very few small colonies] for California vineyard, $20 \%$ index for California greenhouse, and $20 \%$ coverage New York Single isolate) or including moderate (M) progeny as resistant (susceptible thresholds $=3$ [ $<50 \%$ coverage] for California vineyard, $40 \%$ index for California greenhouse, and $40 \%$ coverage for New York single isolate).

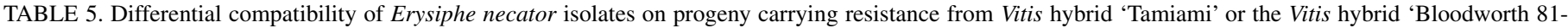
$107-11$

\begin{tabular}{|c|c|c|c|c|c|c|c|c|c|}
\hline \multirow[b]{2}{*}{ Population, progeny } & \multirow[b]{2}{*}{ Rating $^{\mathrm{a}}$} & \multicolumn{8}{|c|}{ E. necator isolate ${ }^{\mathrm{b}}$} \\
\hline & & B1Mtnt2 & WVMONt* & LICY & LNYM & G9 & SHNC1 & PUMOChn & PCTH* \\
\hline \multicolumn{10}{|l|}{ Tamiami (07-3509-) } \\
\hline 162 & $\mathrm{R}$ & \pm & + & - & $\ldots$ & $\ldots$ & $\ldots$ & - & - \\
\hline 215 & $\mathrm{R}$ & + & + & - & $\ldots$ & $\ldots$ & $\ldots$ & - & - \\
\hline 178 & $\mathrm{R}$ & + & + & -* & $\ldots$ & $\ldots$ & $\ldots$ & -* & - \\
\hline 109 & $\mathrm{R}$ & + & - & \pm & $\ldots$ & $\ldots$ & $\ldots$ & \pm & - \\
\hline 191 & $\mathrm{R}$ & + & + & \pm & $\ldots$ & $\ldots$ & $\ldots$ & \pm & - \\
\hline Susceptible & $\mathrm{S}$ & + & + & + & $\ldots$ & $\ldots$ & $\ldots$ & + & + \\
\hline Bloodworth 81-107-11 (07-3510-) & & $\ldots$ & & & & & & & \\
\hline 70 & $\mathrm{R}$ & $\ldots$ & $\ldots$ & $\ldots$ & - & - & - & + & $+*$ \\
\hline Susceptible & $\mathrm{S}$ & $\ldots$ & $\ldots$ & $\ldots$ & + & + & + & + & + \\
\hline
\end{tabular}

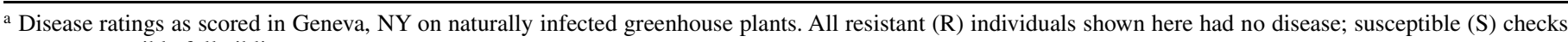
were susceptible full-sibling progeny.

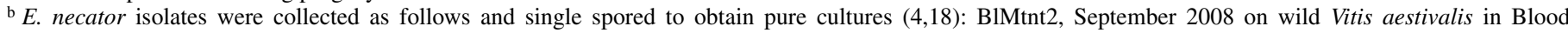
Mountain, GA; LICY, October 2008 on V. vinifera 'Chardonnay' in Riverhead, NY; PUMOChn, October 2008 on Vitis interspecific hybrid 'Chambourcin' in Purdy, MO; WVMONt, September 2008 on Vitis interspecific hybrid 'Norton' in Waverly, MO; PCTH, May 2009 on wild V. rotundifolia in Panther Creek Recreational Area, GA; LNYM, October 2008 on V. vinifera 'Merlot' in Lockport, NY; G9, June 2007 on Vitis interspecific hybrid 'Rosette' in Geneva, NY; and SHNC1, September 2008 on Vitis hybrid Chambourcin in Pittsboro, NC. Symbols: Asterisks (*) denote isolates or individual observations that were not repeated in an independent experiment, + indicates compatible interactions in which the E. necator isolate formed a colony and sporulated following dry pipette tip transfer of conidia, - indicates incompatible interactions, and \pm indicates that a compatible interaction was observed in some but not all independent experiments. 


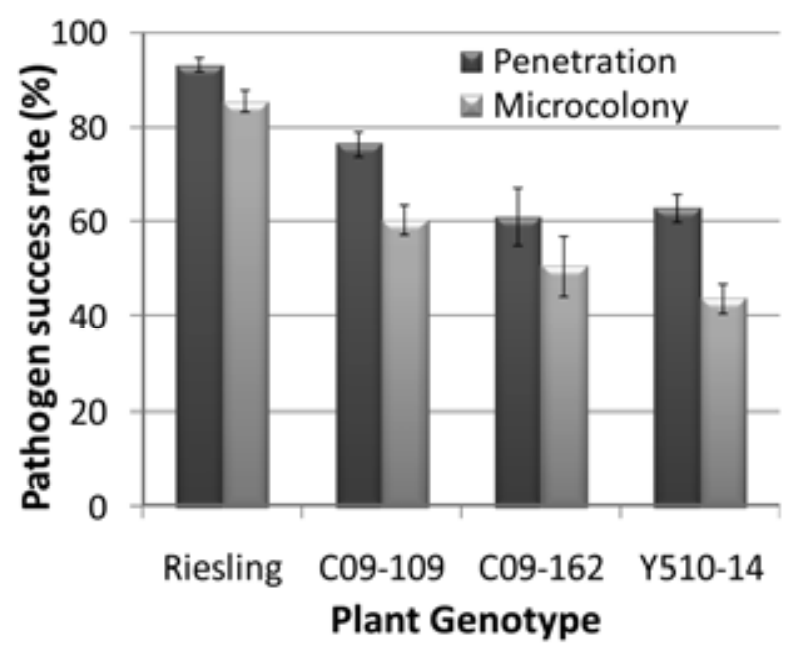

Fig. 2. Percentage of successful penetration and microcolony formation by germinated conidia of an Erysiphe necator isolate incompatible on Vitis hybrid 'Tamiami' and 'Bloodworth 81-107-11' resistance sources. Vitis vinifera 'Riesling' is a susceptible control. C09-109 and -162 are resistant fullsibs derived from Tamiami population 07-3509. Y510-14 is a resistant progeny of Bloodworth 81-107-11 population 07-3510. Error bars represent $95 \%$ confidence limits.

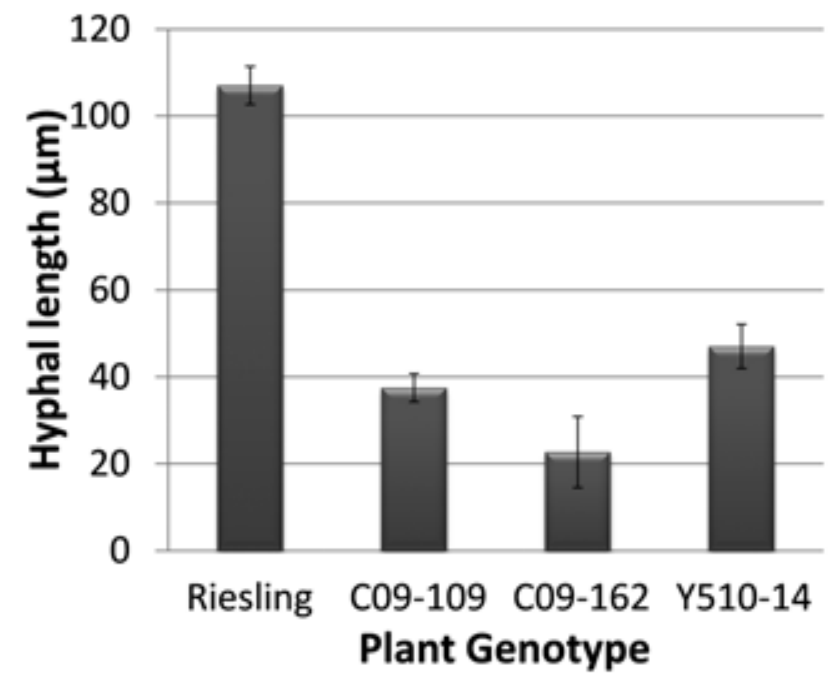

Fig. 3. Hyphal length for an Erysiphe necator isolate incompatible on Vitis hybrid 'Tamiami' and 'Bloodworth 81-107-11' resistance sources. Vitis vinifera 'Riesling' is a susceptible control. C09-109 and -162 are resistant fullsib progeny in Tamiami population 07-3509. Y510-14 is a resistant progeny of Bloodworth 81-107-11 population 07-3510. Colonies were analyzed following $72 \mathrm{~h}$ incubation at $20^{\circ} \mathrm{C}$. Error bars represent $95 \%$ confidence limits. sented here first implicate, then demonstrate, the presence of multiple race-specific resistance genes in the Tamiami and Bloodworth 81-107-11 resistance sources, with resistance hallmarks suggesting that Flor's gene-for-gene model may apply here (17).

In attempting to confirm powdery mildew resistance ratings in mapping populations, we found that ratings for individual progeny were inconsistent and depended on the pathogen genotype or other experimental parameters used for phenotyping. This inconsistency was in stark contrast to parallel results that we obtained in the same experiments with a population segregating for Ren4 resistance, in which individual progeny were either resistant in all three screens or susceptible in all three screens (34). A simple explanation of Mendelian segregation ratios that significantly differed among screens (Tables 3 and 4) is that the inoculum varied, with different races in each pathogen population or isolate used. Experiments testing several single-conidium pathogen isolates on select segregants from each population then provided conclusive evidence of $E$. necator races differentially compatible on resistant Vitis leaves in these populations (Table 5). Following the classical definition of a fungal race, that a single race is virulent on certain host genotypes and not others (11), we have demonstrated race specificity in the E. necator pathosystem.

Isolates collected from wild $V$. aestivalis or the interspecific $V$. aestivalis hybrid Norton (38) sporulated on progeny of the $V$. aestivalis resistance source Tamiami. Similarly, on resistant progeny from the complex hybrid Bloodworth 81-107-11 of at least $V$. rotundifolia, $V$. vinifera, $V$. berlandieri, V. rupestris, V. labrusca, and $V$. aestivalis background, the isolates that sporulated in repeated experiments were from wild $V$. rotundifolia and the complex hybrid Chambourcin-which contains, in its pedigree, most of the wild Vitis spp. of Bloodworth 81-107-11 except $V$. rotundifolia (22). Although intuitive, this apparent host specialization was somewhat surprising, because we previously observed a lack of genetic differentiation among E. necator isolates collected from several Vitis spp. (19) and only minor quantitative variation in host specialization (18), with the notable exception of isolates from $V$. rotundifolia $(18,19)$. Indeed, even in California, where pathogen diversity is low $(4,19)$, we showed here that virulent isolates could be detected by natural infection (e.g., California greenhouse), even within one growing season of selection. Thus, even in the absence of diversity in single-nucleotide protein (4) and simple-sequence repeat markers (19), functional diversity in effector genes appears to be common, which has major implications for the breeding and commercialization of resistant cultivars.

Cellular interactions of the host and pathogen further supported the model of race-specific resistance in each breeding population. Microscopic analyses revealed the ability of conidia landing on resistant genotypes to germinate and penetrate host epidermal cells, as indicated by formation of a secondary hypha (Figs. 2 and
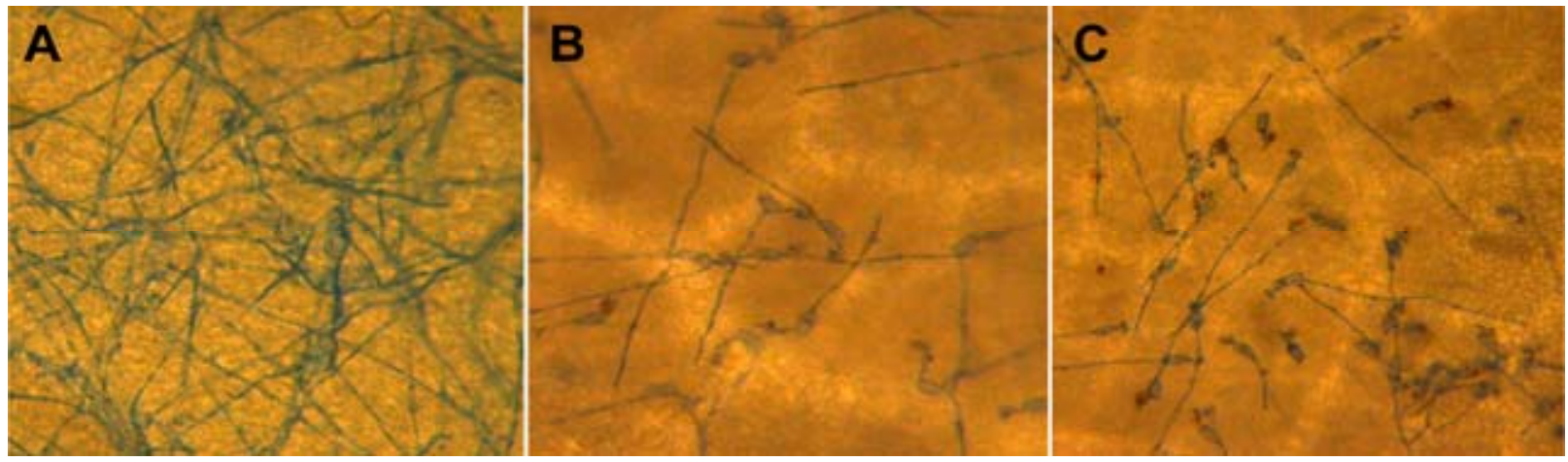

Fig. 4. Colony development for an Erysiphe necator isolate incompatible on characteristic progeny of Vitis hybrid 'Tamiami' and 'Bloodworth 81-107-11' resistance sources. The incompatible isolate was inoculated onto Vitis leaves and visualized with Coomassie blue. A, Hyphal growth on susceptible Vitis vinifera 'Riesling'. B and C, Germinated conidia with secondary hyphae and with appressoria subtended by epidermal cell necrosis on incompatible $\mathbf{B}$, Tamiami-resistant progeny C09-109 and C, Bloodworth 81-107-11-resistant progeny Y510-14. 
4). Each secondary hypha typically elongated more than twice the length of the source conidium to form a microcolony within 3 days of inoculation. No differences were observed in the rates of successful penetration and microcolony formation between resistant progeny from Tamiami and Bloodworth 81-107-11, and resistant progeny from each population allowed only slightly less penetration and microcolony formation than the susceptible control Riesling (Fig. 2). Instead, the major differences between susceptible and resistant genotypes were in hyphal length (Fig. 3), which was restricted and associated with host necrosis in resistant progeny (Fig. 4). Interestingly, the clear differences between resistance and susceptibility would have been underestimated if our screen had looked at penetration and microcolony formation alone and not included measurements of hyphal length. LTSEM data contributed to defining the mechanism of these similar resistances, with conidia, appressoria, and hyphae collapsing shortly after initiation of the secondary hypha (Fig. 5). Together, these data suggest that resistance is acting after formation of the haustorium and is associated with cell death much like the previously described Runl and Renl powdery mildew resistance genes in

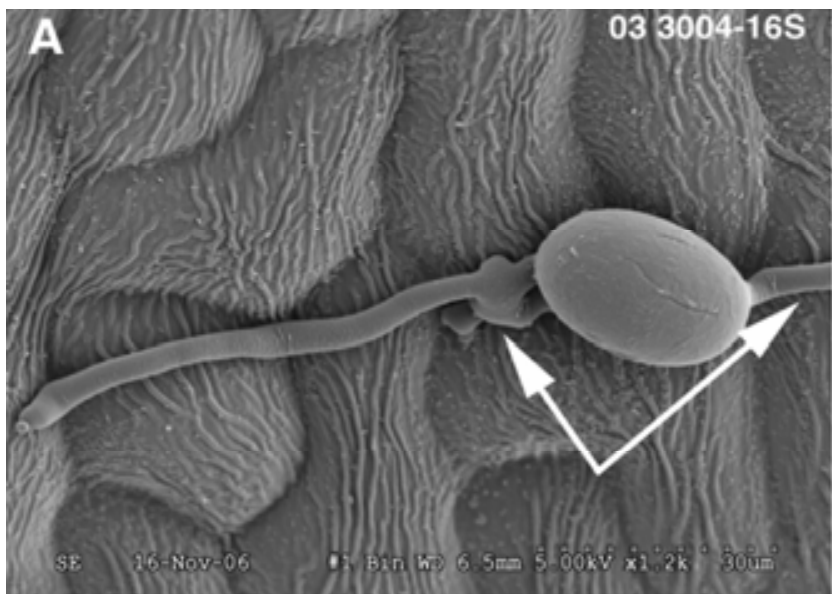

\section{B}

03 3004-16S
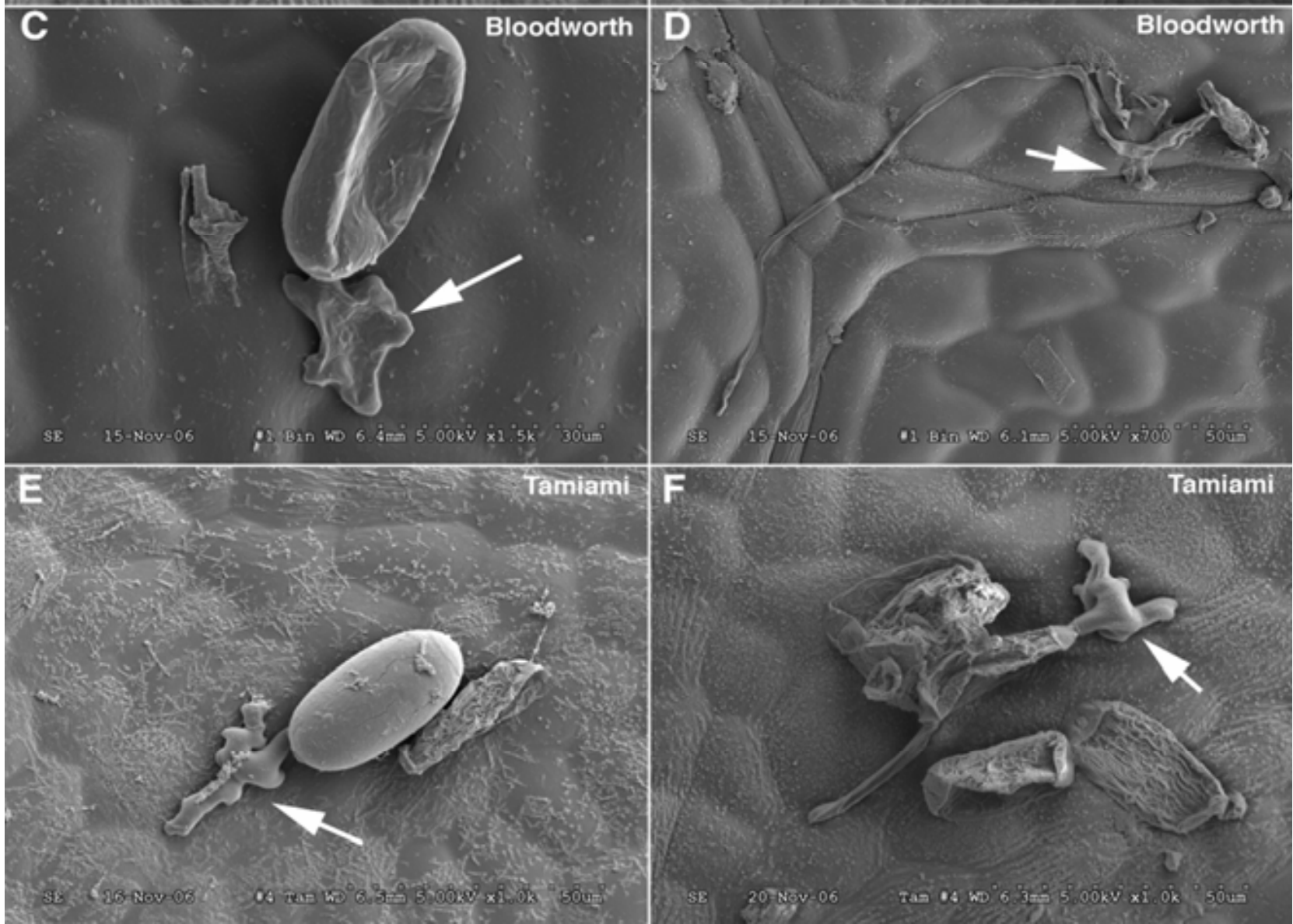

Fig. 5. Low-temperature scanning electron microscopy micrographs of germinated conidia of Erysiphe necator. Each frame is labeled in the upper right with the host genotype name. A and B, Germinated conidia on susceptible Vitis progeny 03-3004-16 from a population segregating for Ren4 (34). A, The conidium has two germ tubes (both arrows) and has formed an appressorium (left arrow). B, A germinated conidium with two long hyphae (larger upper arrows) and five appressoria (smaller lower arrows). Note that the conidia and hyphae in A and B are turgid. C and D, Germinated conidia on seedling of complex hybrid 'Bloodworth 81-107-11'. C, Germinated conidium showing partial collapse of conidium and appressorium (arrow). D, Germinated conidium which formed a long hypha $(+250 \mu \mathrm{m})$ and an appressorium (arrow) but failed to establish a colony. Note the collapsed hypha and appressorium. E and F, Germinated conidia on seedling of Vitis hybrid 'Tamiami'. E, Germinated conidium with a germ tube and the start of an appressorium (arrow). Both conidium and germ tube are turgid. F, Germinated conidia that failed to infect the host. The conidia and one of the germ tubes have collapsed; an appressorium is still partially turgid (arrow). 
Vitis $(3,9)$, and suggest that this host cell death is associated with the rapid collapse of all superficial fungal tissues.

For both resistance sources studied here, powdery mildew incidence and severity increased on some progeny late in the growing season in the Parlier, CA greenhouse, including on old and senescing leaves (Tables 1 and 2). Late-season epidemics on senescing leaves of otherwise resistant progeny are commonly observed in the Parlier, CA vineyard, typically in October and November (D. W. Ramming, unpublished data). These observations lead to two testable hypotheses: (i) virulent isolates are rare early in the season, resulting in low incidence and severity on resistant vines early in the season but high incidence and severity after natural selection throughout the season for virulence; or (ii) when resistant vines begin to enter dormancy and leaves begin to senesce, the action of these powdery mildew resistance genes becomes less effective. However, neither increasing disease ratings nor increasing growth on older leaves in the Parlier greenhouse correlated with resistance or race specificity in the other resistance screens (Tables 1 and 2).

Recently, resistance from Bloodworth 81-107-11 was mapped to the Run2.1 locus on chromosome 18 (36). This locus explained $53 \%$ of the phenotypic variation in foliar powdery mildew severity following natural infections in a Davis, CA greenhouse for a $\mathrm{mBC}_{1}$ population. However, in two $\mathrm{F}_{1}$ populations, the frequency of resistance was more common among progeny than the frequency observed in the $\mathrm{mBC}_{1}$, and no loci-not even Run2.1-significantly predicted foliar resistance in either $\mathrm{F}_{1}$ population (36). The increased frequency of resistant progeny could be due to multiple resistance genes, as seen in the halfsibling $\mathrm{F}_{1}$ population here, and it appears their $\mathrm{mBC}_{1}$ population harbors only one of the two resistance loci we putatively identified as segregating, which are most likely Run2.1 and an unlinked locus. Our variable phenotypic data suggest that race specificity in this resistance source could be a further complicating factor when mapping resistance based on uncontrolled, natural infections. These studies suggest an advantage to using controlled inoculations with differential isolates to develop molecular markers linked with each resistance gene before applying markers to maintain multiple resistance genes in breeding populations.

The identification of several new resistance genes already introgressed from wild species into advanced breeding lines would seem to be a discovery of significant magnitude for the future of resistance breeding, particularly in a crop with few characterized resistance genes. However, this type of resistance can be rapidly overcome by new races of the pathogen shortly after cultivar release $(7,24,27)$ and, in this case, even in segregating populations early in the breeding and evaluation process. As indicated in Tables 3 and 4, each of the up to five putative resistance genes were overcome at least individually and, in some cases, even pairs of resistance genes were overcome, as evidenced by 1:3 segregation ratios. Given that sexual reproduction by E. necator occurs frequently worldwide and is required for winter survival in cold climates $(20,21)$, races that are compatible with host genotypes with the putative pyramid of three resistance genes, as in some Tamiami progeny, would likely arise as a result of recombination. Subsequent selection for compatible races on these resistant cultivars would follow and would eventually result in the breakdown of resistance, as experienced multiple times with wellcharacterized race-specific powdery mildew resistance genes in cereals (15). Some grapevine progeny found to be resistant in California screens were susceptible in the New York screen (Tables 1 and 2), or vice versa, reinforcing the need to test putatively resistant individuals in multiple environments, which is logical but seldom done in woody perennial breeding programs, due in part to the expense of establishing and maintaining plantings. For controlled inoculations, given the low genetic diversity of isolates outside of the eastern United States $(4,19)$, centralized phenotyping with characterized reference isolates of E. necator in the eastern United States is more desirable than dissemination of reference isolates.

We have detected multiple race-specific powdery mildew resistance genes introgressed from several different North American species as well as races of E. necator capable of overcoming them. Although incorporating resistances into breeding material is desirable, the mechanism of the genes identified here is suboptimal. Their sustainable use in grapevine cultivars could be more effective when pyramided, a condition that can be facilitated by developing markers for marker-assisted selection. However, as demonstrated in barley, pyramiding two race-specific resistance genes typically only increased durability by 1 or 2 years compared with a single gene (5). Additional studies are needed to test the effect of combined resistance mechanisms (prehaustorial, posthaustorial, and quantitative) in the development of durable resistance. Therefore, we recommend that new and existing powdery mildew resistances in all crops be mechanistically characterized by quantitative phenotyping, such as with the Coomassie blue protocols described here. This will not only add standardized information to our growing knowledge base but also streamline approaches to the effective and prolonged use of resistance genes in the field.

\section{ACKNOWLEDGMENTS}

This research was supported by the American Vineyard Foundation, California Table Grape Commission, California Raisin Marketing Board, Viticultural Consortium West, the California Competitive Grants Program for Viticulture and Enology, and USDA-ARS.

\section{LITERATURE CITED}

1. Akkurt, M., Welter, L., Maul, E., Topfer, R., and Zyprian, E. 2007. Development of SCAR markers linked to powdery mildew (Uncinula necator) resistance in grapevine (Vitis vinifera L. and Vitis sp.). Mol. Breed. 19:103-111.

2. Ameline-Torregrosa, C., Cazaux, M., Danesh, D., Chardon, F., Cannon, S. B., Esquerre-Tugaye, M. T., Dumas, B., Young, N. D., Samac, D. A., Huguet, T., and Jacquet, C. 2008. Genetic dissection of resistance to anthracnose and powdery mildew in Medicago truncatula. Mol. PlantMicrobe Interact. 21:61-69.

3. Barker, C. L., Donald, T., Pauquet, J., Ratnaparkhe, M. B., Bouquet, A., Adam-Blondon, A. F., Thomas, M. R., and Dry, I. B. 2005. Genetic and physical mapping of the grapevine powdery mildew resistance gene, Run1, using a bacterial artificial chromosome library. Theor. Appl. Genet. 111:370-377.

4. Brewer, M. T., and Milgroom, M. G. 2010. Phylogeography and population structure of the grape powdery mildew fungus, Erysiphe necator, from diverse Vitis species. BMC Evol. Biol. 10:268.

5. Brown, J. K. M. 1994. Chance and selection in the evolution of barley mildew. Trends Microbiol. 2:470-475.

6. Cadle-Davidson, L., Chicoine, D. R., and Consolie, N. H. 2010. Variation within and among Vitis species for foliar resistance to the powdery mildew pathogen Erysiphe necator. Plant Dis. 95:202-211.

7. Caffier, V., and Parisi, L. 2007. Development of apple powdery mildew on sources of resistance to Podosphaera leucotricha, exposed to an inoculum virulent against the major resistance gene Pl-2. Plant Breed. 126:319-322.

8. Coffey, M. D., McCreight, J. D., and Miller, T. 2006. New races of the cucurbit powdery mildew Podosphaera xanthii present in California. (Abstr.) Phytopathology 96:S25.

9. Coleman, C., Copetti, D., Cipriani, G., Hoffman, S., Kozma, P., Kovacs, L., Morgante, M., Testolin, R., and Di Gaspero, G. 2009. The powdery mildew resistance gene REN1 co-segregates with an NBS-LRR gene cluster in two Central Asian grapevines. BMC Genet. 10:89.

10. Dalbo, M. A., Ye, G. N., Weeden, N. F., Wilcox, W. F., and Reisch, B. I. 2001. Marker-assisted selection for powdery mildew resistance in grapes. J. Am. Soc. Hortic. Sci. 126:83-89.

11. D’Arcy, C. J., Eastburn, D. M., and Schumann, G. L. 2001. Illustrated glossary of plant pathology. In: The Plant Health Instructor. American Phytopathological Society, St. Paul, MN.

12. Doster, M. A., and Schnathorst, W. C. 1985. Effects of leaf maturity and cultivar resistance on development of the powdery mildew fungus on grapevines. Phytopathology 75:318-321. 
13. Eibach, R. 1994. Investigations about the genetic resources of grapes with regard to resistance characteristics to powdery mildew (Oidium tuckeri). Vitis 33:143-150.

14. Erickson, E. O., and Wilcox, W. F. 1997. Distributions of sensitivities to three sterol demethylation inhibitor fungicides among populations of Uncinula necator sensitive and resistant to triadimefon. Phytopathology 87:784-791.

15. Finckh, M. R., Gacek, E. S., Goyeau, H., Lannou, C., Merz, U., Mundt, C. C., Munk, L., Nadziak, J., Newton, A. C., de Vallavieille-Pope, C., and Wolfe, M. S. 2000. Cereal variety and species mixtures in practice, with emphasis on disease resistance. Agronomie 20:813-837.

16. Fischer, B. M., Salakhutdinov, I., Akkurt, M., Eibach, R., Edwards, K. J., Topfer, R., and Zyprian, E. M. 2004. Quantitative trait locus analysis of fungal disease resistance factors on a molecular map of grapevine. Theor. Appl. Genet. 108:501-515.

17. Flor, H. H. 1955. Host-parasite interaction in flax rust-its genetics and other implications. Phytopathology 45:680-685.

18. Frenkel, O., Brewer, M. T., and Milgroom, M. G. 2010. Variation in pathogenicity and aggressiveness of Erysiphe necator from different Vitis spp. and geographic origins in the eastern United States. Phytopathology 100:1185-1193.

19. Frenkel, O., Portillo, I., Brewer, M. T., Péros, J.-P., Cadle-Davidson, L., Milgroom, M. G. Development of microsatellite markers from the transcriptome of Erysiphe necator for analyzing population structure in North America and Europe. Plant Pathol. DOI: 10.1111/j.13653059.2011.02502.x.

20. Gadoury, D. M., Cadle-Davidson, L., Wilcox, W. F., Dry, I. B., Seem, R. C., and Milgroom, M. G. 2011. Grapevine powdery mildew (Erysiphe necator): a fascinating system for the study of the biology, ecology, and epidemiology of an obligate biotroph. Mol. Plant Pathol. doi: 10.1111/J.1364-3703.2011.00728.X.

21. Gadoury, D. M., and Pearson, R. C. 1991. Heterothallism and pathogenic specialization in Uncinula necator. Phytopathology 81:1287-1293.

22. Galet, P. 1988. Cépages et Vignobles de France-Tome I: Les Vignes Amércaines. C. Déhan, ed. Montpellier, France.

23. Glawe, D.A. 2008. The powdery mildews: A review of the world's most familiar (yet poorly known) plant pathogens. Annu. Rev. Phytopathol. 46:27-51.

24. Gohre, V., and Robatzek, S. 2008. Breaking the barriers: Microbial effector molecules subvert plant immunity. Annu. Rev. Phytopathol. 46:189-215.

25. Hoffmann, S., Di Gaspero, G., Kovacs, L., Howard, S., Kiss, E., Galbacs, Z., Testolin, R., and Kozma, P. 2008. Resistance to Erysiphe necator in the grapevine 'Kishmish vatkana' is controlled by a single locus through restriction of hyphal growth. Theor. Appl. Genet. 116:427-438.

26. Hvarleva, T. D., Russanov, K. E., Bakalova, A. T., Zhiponova, M. K.,
Djakova, G. J., Atanassov, A. I., and Atanassov, I. I. 2009. Microsatellite linkage map based on F2 population from Bulgarian grapevine cultivar Storgozia. Biotechnol. Biotec. Eq. 23:1126-1130.

27. Jones, J. D. G., and Dangl, J. L. 2006. The plant immune system. Nature 444::323-329.

28. Lebeda, A., Petrzelova, I., and Maryska, Z. 2008. Structure and variation in the wild-plant pathosystem: Lactuca serriola-Bremia lactucae. Eur. J. Plant Pathol. 122:127-146.

29. Leus, L., Dewitte, A., Van Huylenbroeck, J., Vanhoutte, N., Van Bockstaele, E., and Hofte, M. 2006. Podosphaera pannosa (syn. Sphaerotheca pannosa) on Rosa and Prunus spp.: Characterization of pathotypes by differential plant reactions and ITS sequences. J. Phytopathol. 154:2328.

30. Leus, L., Van Huylenbroeckl, J., Van Bockstaelel, E., and Hofte, M. 2008. Early selection of garden rose seedlings for powdery mildew resistance. Eur. J. Hortic. Sci. 73:5-11.

31. Li, H. 1993. Studies on the resistance of grapevine to powdery mildew. Plant Pathol. 42:792-796.

32. Long, M. C., Krebs, S. L., and Hokanson, S. C. 2010. Field and growth chamber evaluation of powdery mildew disease on deciduous azaleas. Hortscience 45:784-789.

33. Mahanil, S., Lagerholm, S., Garris, A., Owens, C. L., Ramming, D. W., and Cadle-Davidson, L. Development of molecular markers for powdery mildew resistance in grapevines. Acta Hortic. (In press.)

34. Ramming, D. W., Gabler, F., Smilanick, J., Cadle-Davidson, M., Barba, P., Mahanil, S., and Cadle-Davidson, L. 2010. A single dominant locus Ren4 confers non-race-specific penetration resistance to grapevine powdery mildew. Phytopathology 101:502-508.

35. Reddy, K. S. 2007. Identification by genetic analysis of two races of Erysiphe polygoni DC causing powdery mildew disease in mungbean. Plant Breed. 126:603-606.

36. Riaz, S., Tenscher, A. C., Ramming, D. W., and Walker, M. A. 2011. Using a limited mapping strategy to identify major QTLs for resistance to grapevine powdery mildew (Erysiphe necator) and their use in markerassisted breeding. Theor. Appl. Genet. 122:1059-1073.

37. Roy, R. R., and Ramming, D. W. 1990. Varietal resistance of grape to the powdery mildew fungus, Uncinula necator. Fruit Var. J. 44:149-155.

38. Stover, E. W., Dangl, G., Yang, J., Bautista, J. C., and Aradhya, M. K. 2010. Investigations into the origin of 'Norton' grape using SSR markers. Proc. Fla. State Hortic. Soc. 122:19-24.

39. Suit, R. F. 1945. Field results on the control of certain grape diseases in New York. N. Y. AES Bull. 712:26.

40. Welter, L. J., Gokturk-Baydar, N., Akkurt, M., Maul, E., Eibach, R., Topfer, R., and Zyprian, E. M. 2007. Genetic mapping and localization of quantitative trait loci affecting fungal disease resistance and leaf morphology in grapevine (Vitis vinifera L). Mol. Breed. 20:359-374. 